Selcuk Journal of Agriculture and Food Sciences

http://sjafs.selcuk.edu.tr/sjafs/index

Research Article
SJAFS

(2020) 34 (1), 49-56

e-ISSN: 2458-8377

DOI:10.15316/SJAFS.2020.194

\title{
Detection of Some Virus Diseases of Edible Seed Squash (Cucurbita pepo L.) in Nevşehir Province, Turkey
}

\author{
Serkan YEŞiL ${ }^{1, *}$ \\ ${ }^{1}$ Selçuk University, Faculty of Agriculture, Department of Plant Protection, Konya, Turkey
}

ARTICLE INFO

Article history:

Received date: 23.11.2019

Accepted date: 17.01.2020

\section{Edited by:}

Murat KARACA; Selçuk University,

Turkey

\section{Reviewed by:}

Şerife TOPKAYA; Gazi Osmanpaşa

University, Turkey

İsmail Can PAYLAN; Ege University, Turkey

\section{Keywords:}

DAS-ELISA,

Edible seed squash,

Nevşehir,

WMV,

Virus

\section{Introduction}

Squash seeds are one of the most nutritionally rich vegetable by-products out there, having a high content of unsaturated fat, protein, beta carotene, vitamin $\mathrm{C}$, vitamin B1, fiber, iron, calcium, and potassium. These seeds were originally a main food for countries like China, United States, India, and Mexico and recently whole world has realized to the health benefits of these seeds. Although edible seed squash has been grown in Turkey for many years, there has been a rapid increase in the production area and quantity since 2004. As a result, in the year of 2018 , edible seed squash production has reached 55.043 tons in about 73.789 ha. production area (TÜİK 2019). In our country, the most important reason for the increase in the production of edible seed squash is that this plant can be grown in both arid and irrigated field conditions. This plant is seen as an economic alternative product that can grow especially in arid conditions. For squash growing, one

\footnotetext{
* Corresponding author email: serkanyesil@selcuk.edu.tr
}

of the most important problems is virus diseases. It's hard to estimate or calculate the amount of yield losses in crops due to virus diseases. According to the different calculations, $3-5 \%$ of overall cultivated vegetable crops are lost because of virus diseases, but these losses can be sometimes very high, where pest control is inadequate, particularly in developing countries (Caciagli 2010). Viruses can cause important economic losses in the world for cucurbit growing. Indeed, on cucurbits, more than 35 different species have been determined as pathogen (Provvidenti 1996). These pathogens cause complicated and dynamically varying problems (Nameth et al 1986). Edible seed squash is one of the most common vegetable crops which is grown in Nevşehir province in Turkey. It occupied 21.165 ha in Nevşehir in 2018, with a predicted production of 16.403 tons (Anonymous 2019). Previous studies from different parts of Turkey have reported different viruses such as Zucchini yellow mosaic potyvirus (ZYMV), Squash mosaic comovirus (SqMV) and Cucumber mosaic cucumovirus (CMV, Cucurbit aphid borne yellows polerovirus (CABYV), Papaya ring spot potyvirus - watermelon strain (PRSV-W), 
Watermelon mosaic potyvirus - 2 (WMV), Cucumber vein yellowing ipomovirus (CVYV), Tomato ring spot nepovirus (TRSV), Melon mosaic virus (MMV), and Tomato black ring nepovirus (TBRV) in the plants of family Cucurbitaceae. (Kurcman 1977; Davis \& Y1lmaz 1984; Nogay \& Yorganc1 1984; Erdiller \& Ertunç 1988; Yılmaz et al 1991; Yılmaz et al 1992; Fidan 1995; Gümüş et al 2001; Çağlar et al 2004).

ZYMV, WMV, and PRSV-W are typical members of Potyvirus genus (Potyviridae), so they have flexuous filamentous particles, and single stranded positive sense RNA genome. Potyviruses can be transmitted efficiently by mechanical inoculation and vector aphid species. ZYMV can be transmitted with seed to a low level, while PRSV-W and WMV are not transmitted with seeds (Lisa \& Lecoq 1984; Purcifull et al 1984a; Purcifull et al. 1984b). CMV is a polyhedral shaped virus that is member of the genus Cucumovirus in the Bromoviridae family and has a three-part genome consisting of ssRNA with positive polarity. This virus can be transmitted by seeds of some hosts, aphids and mechanically (Francki et al 1979). SqMV, which has a positive sense ssRNA genome, belongs to the genus Comovirus (Secoviridae). The particle of the virus is hexagonal formed of isometric subunits and can be transmitted by insect vectors, seed and mechanically (Campbell 1971). CABYV belongs to the genus Polerovirus in the family Luteoviridae (King et al 2012) and was first reported in France in 1992 (Lecoq et al 1992). The virus causes yellowing and thickening of the older leaves in cucurbit plants and is often mistakenly attributed as a nutrient deficiency. Although the major veins of younger leaves would remain green after the infection, plant yield may be reduced (Lecoq et al 1992). The virus is transmitted primarily by Aphis gossypii Glover and Myzus persicae Sulzer, and the transmission could be circulative, persistent, and nonpropagative (Dogimont et al 1996; Gray et al 2014). CABYV has been reported from cucurbit crops across different climatic regions of the world such as temperate, Mediterranean, and subtropical (Lecoq 1999), and no mechanical transmission has been reported (D'Arcy \& Domier 2005). The main constraint for the management of diseases caused by members of Luteoviridae is that no effective strategy exists to cure plants after virus infection (Michelle \& Veronique 2018).

In this study, one year of surveys were carried out for determining the incidence and distribution of viruses (CABYV, CMV, PRSV-W, WMV, SqMV, ZYMV) infecting edible seed squash crops grown in Nevşehir province.

\section{Materials and Methods}

\subsection{Collecting of virus infected squash leaves}

Surveys were conducted by collecting symptomatic squash leaf samples from main squash growing fields in 6 different districts (Center, Acıgöl, Avanos, Der- inkuyu, Gülşehir and Ürgüp) of Nevşehir province during July through September in 2018 (Table 1). In order to samples to represent Nevşehir province, more than $\% 1$ of total edible seed squash growing areas (2 $130 \mathrm{da})$ of the province were surveyed. For this purpose, 24 edible seed squash fields were visited in the province. In these studies, the number of collected samples from each field was determined according to the amount of surface area of the field. So that, at least 5 samples were collected from the fields which have up to $50 \mathrm{da}$ and 8 samples were collected from the fields which have more than 50 da growing areas. The samples were picked from plants which showed virus diseases symptoms like blistering-distortion, mottling, vein clearing, mosaic, yellowing, shoe-string, or stunting and fruit discoloration and deformation. In each field, it was tried to take samples from plants with different symptoms. Five different leaves from each plant showing symptoms of virus diseases were taken as a sample. The samples were tested to determine for the infections of CMV, ZYMV, WMV, SqMV, CABYV and PRSV-W. They were put in plastic bags, and kept in a deep-freezer $\left(-20^{\circ} \mathrm{C}\right)$ until diagnostic tests.

\subsection{Testing by DAS-ELISA}

For determining the virus infections (CABYV, PRSV-W, CMV, WMV, SqMV, and ZYMV) on the squash leaf samples, Double-Antibody Sandwich Enzyme-Linked Immunosorbent Assay (DAS-ELISA) test method was used (Clark and Adams 1977). The antibodies were provided from commercial companies and utilized with respect to the instructions of them. Before the homogenization of the leaf samples, microplates were coated with virus IgG that were diluted in carbonate buffer ( $\mathrm{pH}$ 9.6), and incubated for $4 \mathrm{~h}$ at $37^{\circ} \mathrm{C}$. The squash leaf samples were grinded in a mortar with the addition of the sample extraction phosphate buffer solution at a ratio of 1:10 (PBS, $\mathrm{pH} 7.4)$. After washing the microplates with washing buffer (PBST) thrice, the extracted samples were added to wells and incubated overnight in a refrigerator $\left(+4^{\circ} \mathrm{C}\right)$. Alkaline phosphatase (APP) conjugated antibody diluted in conjugate buffer ( $\mathrm{pH}$ 7.4) was added after washing the plates, and incubated for $4 \mathrm{~h}$ at $37^{\circ} \mathrm{C}$. Substrate buffer (pH 9.8) with Para-nitrophenylphosphate ( $P$-NPP) was added to each well and then, incubated for 30 to 90 min. at dark and room temperature (Fig. 1). Absorbance values were determined at $405 \mathrm{~nm}$ by Anthos 2010 Microplate Reader (Biochrom Ltd., Cambridge, UK). Test was assessed as positive when the average absorbance value of tested sample was greater than two times of healthy (uninfected) control (Abou-Jawdah et al 2000; Yeşil \& Ertunç 2012).

\subsection{Determining infection rates of the viruses}

Numbers of infected plant samples for each virus were determined by DAS-ELISA tests. Infection rates of each virus were calculated by simple proportion. Therefore, for each virus, numbers of sum of single, 
Yeşil / Selcuk J Agr Food Sci, (2020) 34 (1), 49-56

double and multiple virus infected plant samples were divided to numbers of total tested samples then the Table 1

Surveyed districts and number of collected plant samples

\begin{tabular}{lccc}
\hline Districts & Number of collected samples & Number of surveyed fields & Total areas of the fields (da) \\
\hline Nevşehir (Center district) & 15 & 3 & 4 \\
Acrgöl & 20 & 7 & 130 \\
Avanos & 53 & 3 & 400 \\
Derinkuyu & 11 & 4 & 3 \\
Gülşehir & 19 & 24 & 30 \\
Ürgüp & 16 & & 300 \\
\hline Total & 134 &
\end{tabular}

results were multiplied with 100 . In this way, infection rates of each virus were calculated as percentage.
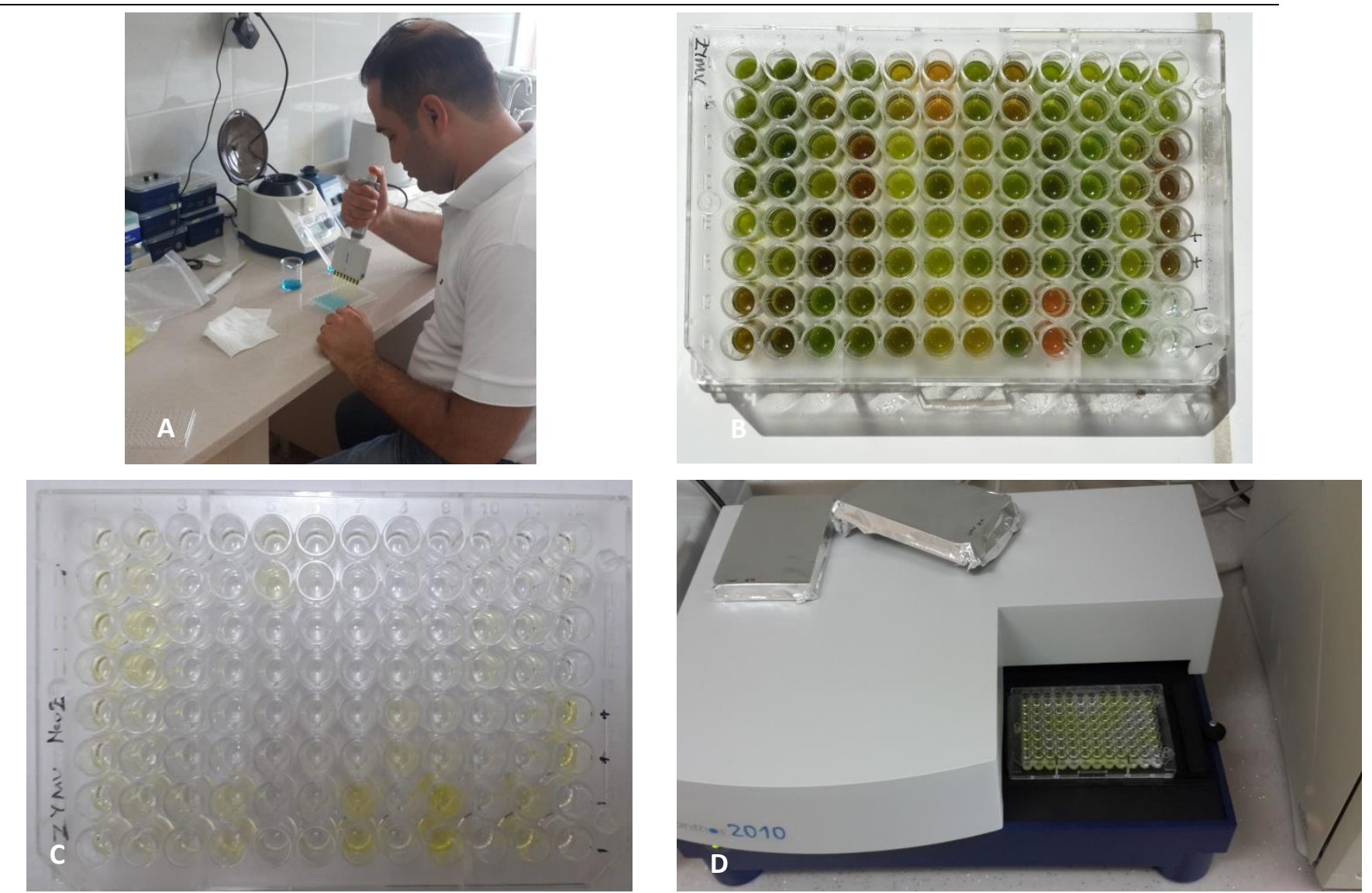

Figure 1

Steps of DAS-ELISA tests. A: Coating wells with virus IgG. B: Extracted samples were added to wells and incubated overnight in a refrigerator $\left(+4^{\circ} \mathrm{C}\right)$. C: Substrate $(P$-NPP) added microplates, incubated for 30 to 90 min. at dark and room temperature. D: End of the incubation, the positive wells got yellow and absorbance values were determined by ELISA reader.

\section{Results and Discussion}

In this study, totally 134 edible seed squash leaf samples were tested by DAS-ELISA. The incidences of the different viruses which infect squash are given in Tables 2 and 3. They obviously show that WMV and ZYMV are the most common squash viruses in the survey area. According to the results of the DASELISA $97.76 \%$ of the samples were infected with CABYV, PRSV-W, ZYMV, CMV, WMV, and SqMV. WMV was the most common virus in the survey area with the ratio of $89.55 \%$. The second important virus disease in the research area was ZYMV; it was detect- ed on the samples at the ratio of $57.46 \%$. They are followed by PRSV-W, SqMV, CABYV and CMV $14.18,2.99,2.23$ and $0.75 \%$ in all tested samples, respectively (Table 2). On 82 of all the samples were determined mixed virus infections. Mixed infections of $\mathrm{WMV}+\mathrm{ZYMV}$ were the most frequently detected ones in the samples with the ratio $40.29 \%$ (Table 3). Double infections with WMV + PRSV-W, WMV + SqMV and ZYMV + PRSV-W were detected as 5.22, 2.98 and $1.49 \%$, respectively. Triple infections of $\mathrm{WMV}+\mathrm{ZYMV}+\mathrm{PRSV}-\mathrm{W}(8.20 \%)$ and WMV + ZYMV + CABYV (1.49\%) were detected in 11 and 2 samples, respectively. According to the DAS-ELISA 
test results, all of the samples which were collected from Nevşehir Center, Acıgöl, Derinkuyu and Ürgüp were determined as virus infected. WMV was the most commonly detected in samples from Ürgüp (100\%), Acıgöl (95\%), Gülşehir (94.74\%) and Derinkuyu (90.91\%). As for ZYMV, PRSV-W, SqMV, and

\section{Table 2}

According to DAS-ELISA tests results, the number of single virus infections

\begin{tabular}{|c|c|c|c|c|c|c|c|c|}
\hline District & No. Tested & Healthy & CMV & SqMV & WMV & PRSV-W & ZYMV & CABYV \\
\hline Nevşehir (Center) & 15 & 0 & 0 & 0 & 3 & 0 & 2 & 0 \\
\hline Acıgöl & 20 & 0 & 0 & 0 & 5 & 0 & 0 & 0 \\
\hline Avanos & 53 & 2 & 0 & 0 & 15 & 0 & 6 & 0 \\
\hline Derinkuyu & 11 & 0 & 0 & 0 & 6 & 0 & 0 & 0 \\
\hline Gülşehir & 19 & 1 & 0 & 0 & 7 & 0 & 0 & 0 \\
\hline Ürgüp & 16 & 0 & 0 & 0 & 5 & 0 & 0 & 0 \\
\hline Total & 134 & 3 & 0 & 0 & 41 & 0 & 8 & 0 \\
\hline
\end{tabular}

Table 3

According to DAS-ELISA tests results, the number of multiple virus infections

\begin{tabular}{|c|c|c|c|c|c|c|c|c|}
\hline \multirow[b]{2}{*}{ District } & \multicolumn{6}{|c|}{ Double virus infections } & \multicolumn{2}{|c|}{ Triple virus infections } \\
\hline & $\begin{array}{l}\text { WMV } \\
+ \text { ZYMV }\end{array}$ & $\begin{array}{l}\text { WMV+ } \\
\text { PRSV-W }\end{array}$ & $\begin{array}{l}\text { WMV } \\
+ \text { SqMV }\end{array}$ & $\begin{array}{l}\text { ZYMV+ } \\
\text { PRSV-W }\end{array}$ & $\begin{array}{c}\text { ZYMV+ } \\
\text { CMV }\end{array}$ & WMV+ CABYV & $\begin{array}{c}\mathrm{ZYMV}+\mathrm{WMV}+ \\
\text { PRSV-W }\end{array}$ & $\begin{array}{c}\text { ZYMV+ } \\
\text { WMV+ } \\
\text { CABYV }\end{array}$ \\
\hline $\begin{array}{l}\text { Nevşehir (Cen- } \\
\text { ter) }\end{array}$ & 9 & 0 & 0 & 0 & 0 & 0 & 1 & 0 \\
\hline Acıgöl & 11 & 0 & 0 & 0 & 1 & 0 & 3 & 0 \\
\hline Avanos & 23 & 2 & 0 & 1 & 0 & 1 & 1 & 2 \\
\hline Derinkuyu & 2 & 2 & 0 & 1 & 0 & 0 & 0 & 0 \\
\hline Gülşehir & 2 & 3 & 0 & 0 & 0 & 0 & 6 & 0 \\
\hline Ürgüp & 7 & 0 & 4 & 0 & 0 & 0 & 0 & 0 \\
\hline Total & 54 & 7 & 4 & 2 & 1 & 1 & 11 & 2 \\
\hline
\end{tabular}

Edible seed squash is economically important in Nevşehir province, but have a high incidence of viruslike symptoms. During the surveys, different symptoms were observed such as leaf deformations (crinkle, blistering, shoe-string, etc.), different chlorotic patterns on leaves (mosaic, ring spot, oak leaf, etc.), fruit deformations and growth reductions on squash plants (Fig.2). Also, symptoms of mineral deficiencies like growth reductions, wilting and yellowing were observed in some fields. The observed diseases symptoms in this study were similar to the symptoms previously reported from virus-infected cucurbits fields worldwide (Makkouk \& Lesemann 1980; Lecoq et al 1981; Sammons et al 1989; Provvidenti 1996; Luis-Arteaga et al 1998; Yuki et al 2000; Davis et al 2002; Massumi et al 2007; Malandraki et al 2014). The occurrence and incidence of viruses on cucurbit plants have been determined in different parts of Turkey. The infection of CMV, CABYV, ZYMV, PRSV-W, WMV, SqMV, and ToMV has been reported in previous studies (Çağlar et al 2004; Davis \& Y1lmaz 1984; Erdiller and Ertunç 1988; Fidan 1995; Korkmaz et al 2018; Köklü \& Y1lmaz 2006; Nogay \& Yorganc1 1984; Şevik \& Balkaya 2015; Topkaya \& Ertunç 2012; Yeşil \& Ertunç 2012; Yeşil 2014; Y1lmaz et al. 1991). But there are a few reports on virus diseases of edible seed squash plants (Yeşil and Ertunç, 2012; Yeşil 2014; 2019a; b). With this study, WMV and ZYMV were determined as the most prevalent viruses in research area. They are effectively transmitted by either infected sap or vector
CABYV were frequently detected in samples from Nevşehir Center (80\%), Gülşehir (47.37\%), Ürgüp (25\%), and Avanos (5.66\%), respectively. CMV infection was only determined on one sample from Acıgöl $(5 \%)$. aphids. These two viruses have been accepted as the most common viruses of cucurbits in the world (Al-Ali et al 2013). Similarly, in a study which was carried out in different provinces of Turkey by Yilmaz et al (1992) WMV and ZYMV were the most widespread viruses among the tested viruses (ZYMV, WMV, CMV, CABYV and PRSV-W). The similar results were reported by Kizmaz et al (2016). These researchers were conducted a survey in cucurbit fields of Mardin and Diyarbakır provinces and they reported that the incidences of WMV $(60.00 \%)$, CMV (43.13\%), ZYMV (39.38\%), PRSV-W (21.25\%) and CABYV (16.25\%). Also, a survey was carried out in Konya province, 334 edible seed squash leaf samples were tested by DASELISA, and ZYMV, WMV and CMV were determined on the samples with the ratios of $60.18 \%, 52.99 \%$ and $13.77 \%$, respectively (Yeşil 2014). The similar results were reported by the Özaslan et al (2006); they carried out a survey study to determine infections of cucurbit viruses in Gaziantep province of Turkey. They reported that ZYMV was the most common virus species on cucurbit plants and, also, the infections of CMV and Potato potyvirus $Y$ (PVY) on cucurbits are common. To reveal viruses of cucurbits in Tokat province, a survey performed by Korkmaz et al (2018). Totally 146 squash plant samples were tested by DAS-ELISA and they found WMV (38.35\%), ZYMV (26.71\%), ToMV (Tomato mosaic tobamovirus) (22.53\%), CMV (13.01) and PRSV-W (5.47\%) infections on the samples. Also, 
they didn't determine any infection of TMV (Tobacco mosaic tobamovirus), SqMV and PVY.

Also, mixed virus infections were determined on 82 of the plant samples with this study (Table 3). In previous studies, mixed virus infections on cucurbits were reported (Kaya \& Erkan 2011; Topkaya et al 2019; Yeşil \& Ertunç 2012; Yeşil 2014; 2019a;b; Yuki et al 2000).

Some of the cucurbit viruses can be transmitted by seeds such as CMV, ZYMV, SqMV, TRSV, and CGMMV. A research was performed to detect the presence of seed borne viruses in pumpkin seed lots collected from Samsun, Sinop, and Bolu provinces during 2013-2014. According to the results of this research, the seed samples were only infected with ZYMV (12.5\%) and CMV (4.1\%). Moreover, any infection wasn't determined on the seeds of SqMV, TRSV, and CGMMV. With another study about determining seed infections of some viruses in major cucurbit growing areas in Konya, Karaman and Aksaray provinces of Turkey during 2009 and 2010. The results of this study showed that $8,7 \%$ of seed samples were infected with ZYMV (4,3\%), WMV (3,3\%) and CMV $(1,1 \%)$. PRSV-W, SqMV and CGMMV were not de- termined in any of the tested samples and were not present in the tested cucurbit seeds lots (Yeşil \& Ertunç 2016). As can be seen in the above mentioned studies, the reason of occurring frequently infections on cucurbits by the viruses such as ZYMV, WMV and CMV may be infected seeds.

In the present study, WMV and ZYMV were detected as most common viruses. In previous studies, similar viruses were detected in different incidences (Erdiller \& Ertunç 1988; Fidan 1995; Korkmaz et al 2018; Köklü \& Y1lmaz 2006; Nogay \& Yorganc1 1984; Şevik \& Balkaya, 2015; Yeşil \& Ertunç, 2012; Yeşil 2014; 2019a; b; Y1lmaz et al 1991). It may be two main reasons for this. Firstly, although other cucurbit crops are grown only in irrigated fields, edible seed squash plant can be grown in either irrigated or semi-arid conditions. The second reason is regional differences. It's normal that, different viruses infect to the same plant species in different environmental conditions. Because differentiations in environmental conditions determine significantly some factors which effect virus epidemiology. These factors are populations and varieties of weed and vector species in or near fields, plant species which are grown in adjacent fields and plant vitality.
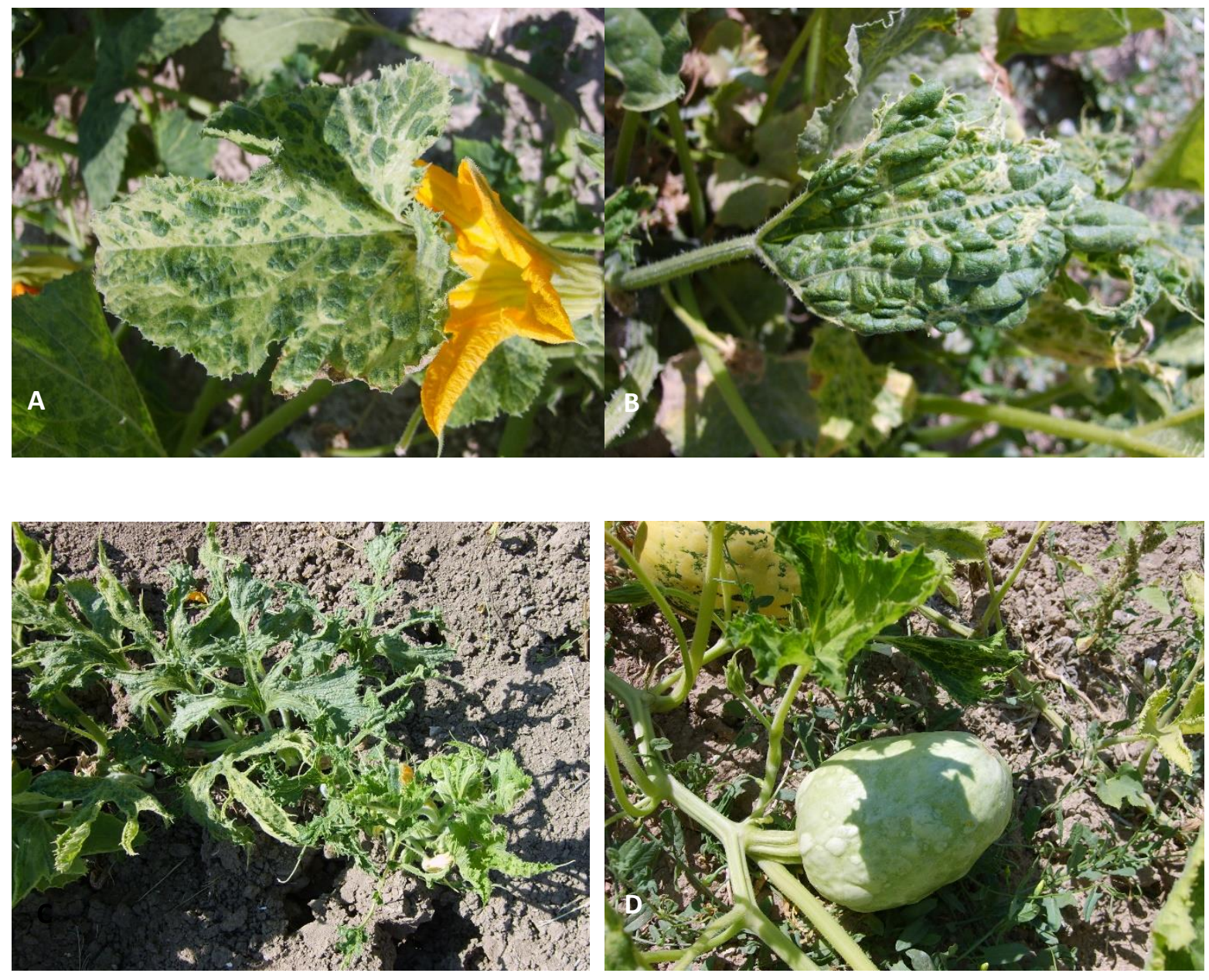

Figure 2

Virus diseases symptoms on edible seed squash plants. A: Mosaic symptoms on the leaf caused by WMV. B: Severely leaf deformations and blisters on the leaf because of ZYMV+WMV double infection. C: Shoestring symptoms on 
squash leaves because of ZYMV+CMV double infections and (D) blisters on fruit because of ZYMV+WMV double infections.

\section{Conclusions}

The presences of CABYV, CMV, PRSV-W, WMV, ZYMV, and SqMV on edible seed squash were firstly detected in Nevşehir with the study. The results showed that one of the most important problems in squash growing in the province is virus infections. Because, during the survey studies, symptoms of virus diseases were observed almost each edible seed squash fields in the province. According to the results of this study, for reducing or eradication of virus diseases in squash production areas in Nevşehir province and can be produced more yielded and more quality edible squash seeds the following suggestions must be regarded.

First of all, healthy, non-infected, pathogen-free and certified seed should be used.

For controlling virus diseases efficiently, it is very important to know about transmission ways and infection sources of the viruses. It's known that, except of SqMV, all viruses detected in our study were spread by mechanical inoculation and aphids (Kaper \& Waterworth 1981). Unfortunately, squash growers in the province neither know symptoms of virus diseases nor know transmission ways of the viruses from plant to plant. Therefore, they are not able to efficiently control virus diseases as they can't prevent the spread of viruses via vector aphid species.

Also, some of the common weed species in squash growing areas have a great importance in the epidemiology of virus diseases because they role as reservoir plants for virus diseases (Zitter 2002; Yeşil \& Ertunç 2015). For preventing virus infection of cucurbits, weeds must be controlled.

As well in other plant crops production, in squash production cultural practices are very important. If all conditions which are necessary for growing healthy plant can be obtained, possibility of chance of phytopathological problems occurrence will be minimum. Therefore, cultural practices such as tilling, planting, fertilizing and irrigation should be done properly.

The plants which show virus diseases symptoms should be eradicated as soon as seen. Since, they act as infection sources for later infections.

\section{References}

Abou-Jawdah Y, Sobh H, El-Zammar S, Fayyad A, Lecoq H (2000). Incidence and management of virus diseases of cucurbits in Lebanon. Crop Protection, 19:217-224.

Al-Ali EA, Al-Hashash H, Al-Aqeel H, Ben HA (2013). Multiple important plant viruses are present on vegetable crops in Kuwait. Journal of Clinical Trials 3, 136. doi:10.4172/2167-0870.1000136.
Anonymous (2019). 2016-2018 yılları Nevşehir ili çerezlik kabak bitkileri üretim değerleri. Nevşehir İl, Gıda, Tarım ve Hayvancılık Müdürlüğü

Caciagli P (2010). Vegetable Viruses. Pages 479-487 in: Desk Encyclopedia of Plant and Fungal Virology. Mahy, BWJ and Van Regenmortel, MHV eds. Academic Press, Linacre House, Jordan Hill, Oxford, OX2 8DP, UK.

Campbell RN (1971). Squash mosaic virus. Descriptions of Plant Viruses. [http://www.dpvweb.net/dpv/showdpv.php?dpvno= 43] (Date of access: 20.03.2019).

Clark MF, Adams AN (1977). Characteristics of the microplate method of enzyme-linked immunosorbent assay for the detection of plant viruses. Journal of General Virology 34:475-783.

Çağlar BK, Guldur ME, Yılmaz MA (2004). First report of Squash mosaic virus in Turkey. Journal of Plant Pathology 86 (2), 177-180.

D'Arcy CJ, Domier LL (2005). Luteoviridae, p891900. In Fauquet CM, Mayo MA, Maniloff J, Desselberger U, Ball LA (ed). Virus taxonomy, VIIIth report of the ICTV. Elsevier/Academic Press, London, United Kingdom.

Davis RF, Y1lmaz MA (1984). First Report of Zucchini Yellow Mosaic Virus on Watermelon and Squash in Turkey. Plant Disease 68:537

Davis RI, Thomas JE, McMichael LA, Dietzgen RG, Callaghan B, James AP, Gunua TG, Rahamma S (2002). Plant virus surveys on the island of New Guinea and adjacent regions of northern Australia. Australasian Plant Pathology 31: 385-390.

Dogimont C, Slama S, Martin J, Lecoq H, Pitrat M (1996). Sources of resistance to Cucurbit aphidborne yellows Luteovirus in a melon germ plasm collection. Plant Disease 80:1379-1382. Doi:10.1094/PD-80-1379.

Erdiller G, Ertunç F (1988). Identification of muskmelon viruses in Ankara province. Journal of Turkish Phytopathology 17:47-56.

Fidan U (1995). Virus diseases of vegetables in greenhouses in Izmir and Mugla. Journal of Turkish Phytopathology 24:7-14.

Francki RIB, Mossop DW, Hatta T (1979). Cucumber mosaic virus. Descriptions of Plant Viruses. [http://www.dpvweb.net/dpv/showdpv.php?dpvno= 213]. (Date of access: 20.03.2019).

Gray S, Cilia M, Ghanim M (2014). Circulative, "nonpropagative" virus transmission: an orchestra of virus-, insect-, and plant-derived instruments. Advances in Virus Research 89:141-199. doi:10.1016/B978-0-12-800172-1.00004-5.

Gümüş M, Erkan S, Yorganc1 U, Duman I (2001). The investigation on the determination of viruses in the seeds of certain vegetables. Proceedings of the IX. 
Phytopathology Congress of Turkey. 3-8 September 2001, Tekirdağ, Turkey. 190-197.

Kaper JM, Waterworth HE (1981). Cucumoviruses. In: Handbook of Plant virus Infections and Comparative Diagnosis. E. Kurstak, ed. Pages 257-332. Elsevier/North Holland Biomedical Press, Amsterdam, the Netherlands.

Kızmaz MZ, Sagır A, Baloglu S (2016). Diyarbakır ve Mardin İlleri Kabakgil Üretim alanlarında Görülen Viral Hastalıkların Yaygınlıklarının ve Etmenlerinin Belirlenmesi. Ege Üniversitesi Ziraat Fakültesi Dergisi, 53 (4):397-406.

King A, Adams M, Carstens E, Lefkowitz E (2012). Virus taxonomy: ninth report of the International Committee on Taxonomy of Viruses. Academic Press, London, United Kingdom

Korkmaz F, Topkaya Ş, Yanar Y (2018). Tokat Kabakgil Üretim Alanlarında Enfeksiyon Oluşturan Virüslerin Belirlenmesi. Gaziosmanpaşa Bilimsel Araştırma Dergisi 7 (2): 46-56.

Köklü G, Yılmaz O (2006). Occurrence of cucurbit viruses on field-grown melon and watermelon in the Thrace region of Turkey. Phytoprotection, 87:123-130.

Kurcman S (1977). Determination of virus diseases on cultural plants in Turkey. Journal of Turkish Phytopathology 6:25-46.

Lecoq H, Pitrat M, Clement M (1981). Identification et caractérisation d'un potyvirus provoquant la maladie du rabougrissement jaune du melon. Agronomie 1: 827-834.

Lecoq H, Bourdin D, Wipf-Scheibel C, Bon M, Lot H, Lemaire O, Herrbach E (1992). A new yellowing disease of cucurbits caused by a Luteovirus, Cucurbit aphid-borne yellows virus. Plant Pathology 41: 749-761. doi: 10.1111/j.1365-3059.1992.tb02559.x.

Lecoq H (1999). Epidemiology of Cucurbit aphidborne yellows virus, p 243-248. In Smith HG, Baker $\mathrm{H}$ (ed). The Luteoviridae. CABI Publishing, Wallingford, United Kingdom.

Lisa V, Lecoq H (1984). Zucchini yellow mosaic virus. Descriptions of Plant viruses. [http://www.dpvweb .net/dpv/ showdpv.php?dpvno=282]. (Date of access: 20.03.2019).

Luis-Arteaga M, Alvarez JM, Alonso-Prados JL, Bernal JJ, Garcia-Arenal F, Lavina A, Batlle A, Moriones E (1998). Occurrence, distribution, and relative incidence of mosaic viruses infecting fieldgrown melon in Spain. Plant Disease 82: 979-982.

Makkouk KM, Lesemann DE (1980). A severe mosaic of cucumbers in Lebanon caused by Watermelon mosaic virus-1. Plant Disease 64: 799-801.

Malandraki I, Vassilakos N, Xanthis C, Kontosfiris G, Katisand NI, Varveri C (2014). First report of Moroccan watermelon mosaic virus in Zucchini crops. Plant Disease 98(5): 702.
Massumi H, Samei A, Pour AH, Shaabanian M, Rahimian H (2007). Occurrence, Distrubution, and Relative Incidence of Seven Viruses Infecting Greenhouse-Grown Cucurbits in Iran. Plant Disease 91:159-163.

Michelle H, Veronique B (2018). Targeted disruption of aphid transmission: a vision for the management of crop diseases caused by Luteoviridae members. Current Opinion in Virology 33:24-32. doi: 10.1016/j.coviro.2018.07.007.

Nameth ST, Dodds JA, Paulus AO, Laemmlen FF (1986). Cucurbit viruses of California: an everchanging problem. Plant Disease 70: 8-11.

Nogay A, Yorganc1 U (1984). Investigations on the identification, seed transmission and host range of viruses infecting the culture plants in the Cucurbitaceae in Marmara region. 1. The identification of viruses infecting cucurbits in Marmara region. Journal of Turkish Phytopathology 13:9-28

Özaslan M, Aytekin T, Bas B, Kilic H, Afacan ID, Dag DS (2006) Virus Diseases of Cucurbits in Gaziantep, Turkey. The Plant Pathology Journal 5, 24-27.

Provvidenti R (1996). Diseases caused by viruses. In: Zitter TA, Hopkins DL, Thomas CE (eds), Compendium of Cucurbit Diseases, Minnesota, USA, APS Press, pp. 37-45.

Purcifull D, Edwardson J, Hiebert E, Gonsalves D (1984a). Papaya ringspot virus. Descriptions of Plant Viruses. [http://www.dpvweb.net/dpv/showdpv.php?dpvno =292]. (Date of access: 20.03.2019).

Purcifull D, Hiebert E, Edwardson J (1984b). Watermelon mosaic virus 2. Descriptions of Plant Viruses.

[http://www.dpvweb.net/dpv/showdpv.php?dpvno= 293]. (Date of access: 20.03.2019).

Sammons B, Barnett OW, Davis RF, Mizuki MK (1989). A survey of viruses infecting yellow summer squash in South Carolina. Plant Disease 73: 401-404.

Şevik MA, Balkaya A, (2015). Samsun, Sinop ve Bolu İllerindeki Bal Kabağı (Cucurbita moschata Duch) Popülasyonlarına Ait Tohum Örneklerinde Virüslerin Tanılanması ve Bulunma Durumlarının Belirlenmesi. Gaziosmanpaşa Üniversitesi Ziraat Fakültesi Dergisi 32(3):70-77.

Topkaya S, Ertunc F (2012). Current status of virus infections in cucurbit plantations in Ankara and Antalya provinces. Proceedings of the Xth EUCARPIA Meeting on Genetics and Breeding of Cucurbitaceae, 759-762.

Topkaya, S, Desbiez, C, Ertunc, F (2019). Presence of cucurbit viruses in Ankara and Antalya province and molecular characterization of coat protein gene of zucchini yellow mosaic virus turkish isolates. 
Fresenius Environmental Bulletin 28(4): 24422449.

TÜİK (2019). 2018 yılı Türkiye çerezlik kabak ekim alanı ve üretim miktarları. www.tuik.gov.tr (Date of access: 14.07.2019)

Yeşil S, Ertunç F (2012). Virus Diseases of Cucurbits in Konya Province. In: Proceedings of the Xth EUCARPIA meeting on genetics and breeding of $\mathrm{Cu}-$ curbitaceae (eds. Sari, Solmaz and Aras), October, 15-18th, 2012, Antalya, Turkey, pp. 791-796.

Yeşil S (2014). Virus Diseases of Edible Seed Squash (Cucurbita pepo L.) in Konya Province. In: Book of Proceedings Fifth International Scientific Agricultural Symposium (AGROSYM-2014), October, 2326th, 2014, Jahorina, Sarajevo, BosniaHerzegovina, 226 p. ISBN: 978-99955-751-9-9

Yeşil S (2019a). Some Virus Diseases of Edible Seed Squash (Cucurbita pepo L.) in Aksaray Province, Turkey. Yüzüncü Yll Üniversitesi Tarım Bilimleri Dergisi 29:63-71.

Yeşil S (2019b). Detection of Viruses on Edible Seed Squash (Cucurbita pepo L.) in Yozgat Province, Turkey. Iğdır Üniversitesi Fen Bilimleri Enstitüsü Dergisi 9 (3):1202-1219.

Yeşil S, Ertunç F (2015). Reservoir Weeds of Cucurbit Viruses in Central Anatolia. In: Proceedings of the International Congress on Applied Biological Sciences (ICABS-2015). September 16-20, 2015, Skopje, Macedonia, 36 p.
Yeşil S, Ertunç F (2016). Seed Transmission of Some Cucurbit Viruses in Turkey. In: Proceedings of the International Conference on Agricultural, Biological and Environmental Sciences (ICABES-2016). December 14-16, 2016, Pattaya, Thailand, 104 p. ISBN:978-93-84468-80-4

Yılmaz MA, Özaslan M, Baloğlu S (1991). Çukurova bölgesinde yetistiriciligi yapılan kavun, karpuz ve hıyar bitkilerine zararlı yeni bir virüs hastalığı. Turkiye VI. Fitopatoloji Kongresi. Izmir-Turkiye, 387-391.

Yılmaz MA, Lecoq H, Abak K, Baloglu S, Sarı N (1992). Türkiye'de kabakgil sebze türlerinde zarar yapan virüsler. Türkiye I. Ulusal Bahçe Bitkileri Kongresi, İzmir, Bildiriler kitab1, 439-442.

Yuki VA, Rezende JAM, Kitajima EW, Barroso PAV, Kuniyuki H, Groppo GA, Pavan MA (2000). Occurrence, distribution, and relative incidence of five viruses infecting cucurbits in the state of Sao Paulo, Brazil. Plant Disease 84: 516-520.

Zitter AT (2002). A checklist of major weeds and crops as natural hosts for plant viruses in the Northeast. Department of Plant Pathology, Cornell University, Ithaca, NY, New York. (Date of access: 20.03.2019)

http://vegetablemdonline.ppath.cornell.edu/Tables/ WeedHostTable.html\#Keys. 